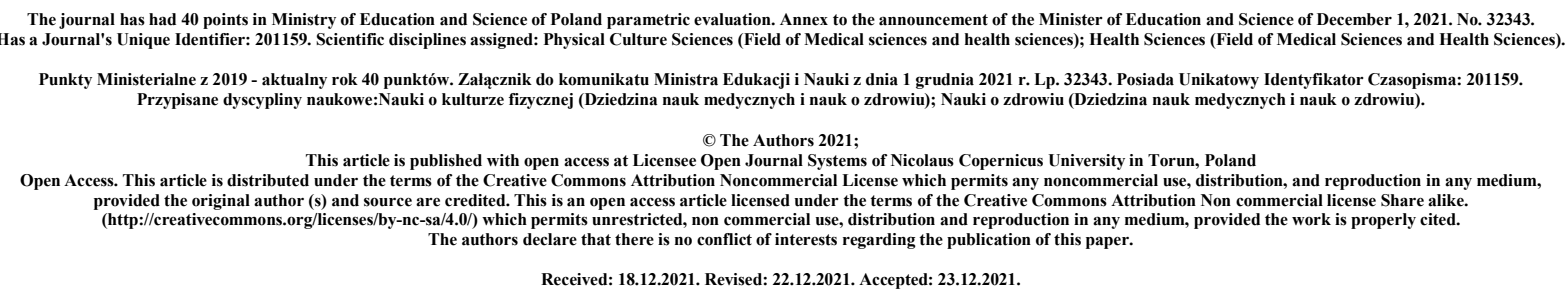

\title{
Psychological determinants of the use of complementary and alternative medicine - CAM
}

\section{Joanna Księska-Koszałka}

ORCID: 0000-0002-8777-3545

e-mail: joannaksieska-koszalka@o2.pl

Institute of Psychology, Maria Curie-Sklodowska University, ul. Głęboka 45, 20-612 Lublin

Introduction and purpose. Today, there is a growing popularity of complementary and alternative medicine (CAM). The phenomenon is based on a number of conditions that are of interest to social sciences. These studies encounter a number of methodological difficulties. The aim of the article is to present the psychological determinants of CAM application in the light of the literature on the subject. The presentation of the state of knowledge was preceded by an extensive theoretical introduction due to the scarcity of current Polish studies on the discussed subject in the literature on health psychology. A review of research works from 1990-2021 in databases available on Ebsco resources, i.e. Medline, APA PsycArticles, APA PsycInfo, CINAHL; in the Google Scholar search engine; literature lists of found articles and in own resources.

Brief description of knowledge. There are relatively few existing studies on this phenomenon, and the results of the studies to date are often contradictory. The best-known determinants of CAM use are environmental and cognitive factors related to cognitive styles and beliefs. Factors related to spirituality and religiosity are also of great importance. Least is known about personality and emotional factors.

Summary. The subject of psychological determinants of CAM application requires further research. A deeper understanding of the determinants of the phenomenon will allow for a better understanding of the needs and expectations of patients that underlie health attitudes.

Key words: complementary and alternative medicine, health attitudes, health behaviours, psychological factors 


\section{Wprowadzenie i cel pracy}

Współcześnie mamy do czynienia z prężnym rozwojem medycyny akademickiej, nowoczesnych technologii i postępów farmakoterapii. Dzięki nim udaje się z powodzeniem leczyć wiele nieuleczalnych wcześniej schorzeń i dawać nadzieję chorym. Wzrasta również świadomość zdrowotna społeczeństwa dotycząca profilaktyki i leczenia. Mimo to na całym świecie obserwujemy niesłabnącą coraz większą popularność medycyny komplementarnej i alternatywnej (complementary and alternative medicine - CAM). W niektórych krajach odsetek osób stosujących te terapie wynosi ponad 50\%. W sposób oczywisty fenomen tak dużego rozpowszechnienia CAM nurtuje wielu badaczy, którzy próbują zrozumieć, jakie czynniki kształtują pozytywne postawy wobec tych metod leczenia. Celem artykułu jest przedstawienie psychologicznych uwarunkowań zjawiska $\mathrm{w}$ świetle literatury przedmiotu.

$\mathrm{Z}$ uwagi na mnogość terminów i definicji funkcjonujących w obrębie CAM (np. medycyna naturalna, niekonwencjonalna, alternatywna, tradycyjna, ludowa, paramedycyna) NCCAM w USA (NCCAM - National Center od Complementary and Alternative Medicine Narodowe Centrum Medycyny Komplementarnej i Alternatywnej, obecnie NCIH - National Center of Complementary and Integrative Health - Narodowe Centrum Zdrowia Komplementarnego i Integracyjnego) zaproponowało definicję, by ujednolicić stosowaną w literaturze terminologię. Zgodnie $\mathrm{z}$ definicją NCCAM Complementary and Alternative Medicine (CAM) stanowią ,grupy różnych systemów leczenia i opieki zdrowotnej, produkty i praktyki, które nie są częścią medycyny konwencjonalnej" [1]

. Jednocześnie NCCAM zaznacza, że medycyna komplementarna i alternatywna są pojęciami rozłącznymi. Praktyki medycyny komplementarnej są i mogą być stosowane razem $\mathrm{z}$ praktykami medycyny konwencjonalnej, podejście alternatywne natomiast obejmuje działania lecznicze podejmowane zamiast tego, co ona [1].

W Polsce rozpowszechnił się termin lecznictwo niemedyczne funkcjonujący przede wszystkim na gruncie socjologii, wprowadzony przez Piątkowskiego [2] Pisze on, że lecznictwo niemedyczne to „działania na rzecz zdrowia, które medycyną nie są, a wywodzą się $\mathrm{z}$ różnorodnych tradycji kulturowych, społecznych i odwołują się do rozmaitych doświadczeń terapeutycznych dawnej medycyny, tradycyjnego chłopskiego lecznictwa ludowego (metody znachorskie) i metod samolecznictwa". To, co najsilniej odróżnia medycynę akademicką od lecznictwa medycznego, to „status naukowy, umocowanie w systemie legislacyjnym oraz posiadanie (lub nieposiadanie) spójnego kodeksu deontologiczno - etycznego wyznaczającego standardy postępowania w procesie leczenia” [3]. W sposób oczywisty lecznictwo niemedyczne wymienionych trzech elementów nie posiada.

Jeśli chodzi o popularność CAM na świecie, przegląd danych pochodzących z różnych populacji pokazuje że rozpowszechnienie CAM w różnych krajach waha się w obrębie 9,8$76 \%$ [4]. W Polsce brak aktualnych danych na ten temat, z badań przeprowadzonych w $2011 \mathrm{r}$. wynika, iż korzystanie z CAM deklaruje ok. 24\% osób [5].

Z uwagi na mnogość i duże zróżnicowanie terapii w obrębie CAM, dokonało także propozycji klasyfikacji systemów leczenia [1]:

- alternatywne systemy medyczne - (whole medical systems) np. medycyna chińska, ajurwedyjska, homeopatia - całościowe systemy teorii i praktyki medycznej;

- medycyna ciała i umysłu (mind-body therapies) - metody bazujące na założeniu powiązania ze sobą ciała i psychiki - m.in. praca z ciałem, relaksacja, yoga; 
- terapie biologiczne - (biologically based therapies) - terapie oparte o biologicznie czynne substancje dostępne $\mathrm{w}$ przyrodzie - m.in. naturoterapię, dietoterapię, ziołolecznictwo, suplementację np. preparatami witaminowymi;

- terapie manualne - (manipulative and body-based therapies) wykorzystujące terapie dłońmi, które wykonują różne zabiegi na ciele np. różnego rodzaju masaże, osteopatia, chiropraktyka;

- terapie energią (energy medicine) - metody oddziaływania na pola energetyczne człowieka, np. bioenergoterapia, reiki.

Biorąc pod uwagę powyższy podział, widać wyraźnie, że różne grupy terapii CAM mają zróżnicowany stopień możliwości weryfikacji jej efektów i tym samym możliwości usankcjonowania na gruncie naukowym. W sposób oczywisty przekłada się to na trudności metodologiczne $\mathrm{w}$ badaniach nad CAM i różnice indywidualne $\mathrm{w}$ podejściu do tych terapii przez ich zwolenników. Oprócz tego, omawiane trudności obejmują także różnice w popularności i dostępności CAM w różnych krajach i odmienności w regulacjach prawnych ich dotyczących. Poszczególne kraje i części świata różnią się również pod względem tradycji W zakresie praktyk zdrowotnych oraz uwarunkowań związanych z funkcjonowaniem systemu opieki medycznej. Oczywiście odmienne wyniki zdrowotne otrzymywać będą użytkownicy CAM o różnym stanie zdrowia, podobnie efekty leczenia terapiami CAM będą zróżnicowane W zależności od tego, czy będą stosowane w profilaktyce czy leczeniu, co również ma istotny wpływ na interpretowanie wyników otrzymanych badań [6,7]. Widać więc wyraźnie, że badacz zajmujący się CAM napotyka na szereg metodologicznych trudności.

\section{Integracja CAM i medycyny konwencjonalnej}

Z uwagi na rosnącą na całym świecie popularność CAM poszczególne instytuty naukowe, w tym przede wszystkim wspomniane wcześniej NCIH i Światowa Organizacja Zdrowia (WHO) postulują wzmożenie badań nad efektywnością poszczególnych metod uzdrawiania [8,9]. Postulaty te mają na celu wzrost bezpieczeństwa pacjentów tj. minimalizowanie zagrożeń wynikających ze szkodliwego sposobu używania CAM bądź stosowania terapii niosących duże ryzyko pogorszenia stanu zdrowia, czy całkowitej rezygnacji z leczenia konwencjonalnego i opieki medycznej na rzecz CAM. Z drugiej strony coraz częściej zalecane jest wykorzystanie różnorakich profitów zdrowotnych, jakie może przynieść CAM np. w profilaktyce i prewencji chorób, na tym gruncie doskonale realizować można idee włączania pacjenta w proces leczenia. Nie sposób wspomnieć w tym kontekście o istnieniu postulatu Integrative Health i funkcjonowaniu tzw. Medycyny Integracyjnej, która łączy zdobycze konwencjonalnej medycyny akademickiej z terapiami z grupy complementary, które uzupełniają podejście stricte medyczne o interwencje z zakresu zdrowego stylu życia, np. dietoterapię, suplementację, praktyki psychologiczne i psychoterapeutyczne, praktyki o charakterze religijnym/duchowym (np. joga, medytacja, modlitwa) oraz terapie manualne $[9,10]$. Coraz więcej szpitali i placówek medycznych poszerza więc swoją ofertę dla pacjentów o terapie komplementarne. W znaczący sposób ułatwia to prowadzenie badań nad CAM, których wyniki prezentowane są w wysokopunktowanych czasopismach z listy JCR np. Complementary Therapies in Medicine, Journal of Traditional and Complementary Medicine, BMC Complementary Medicine and Therapies czy Evidence-Based Complementary and Alternative Medicine. W Polsce w 2017 roku postało Towarzystwo Lekarzy Medycyny Zintegrowanej, która skupia medyków zainteresowanych terapiami komplementarnymi. W ramach działalności towarzystwa również prowadzone są badania naukowe nad CAM oraz sympozja i konferencje poświęcone zagadnieniom integracji medycyny akademickiej i CAM [11]. 
Rozwojowi zainteresowań praktykami CAM sprzyjają media społecznościowe. Choć $\mathrm{w}$ ostatnich latach $\mathrm{w}$ Polsce nie prowadzono statystyk na temat rozpowszechnienia CAM, ogromna popularność takich osób, jak naturoterapeuta Jerzy Zięba ${ }^{1}$, autor 3 tomów Ukrytych terapii (jego funpage na FB polubiło prawie 350 tys. osób, a niektóre jego filmy na portalu Youtube obejrzało ponad milion użytkowników - dane z dnia 9 września 2021 r.) czy lekarz integracyjny Hubert Czerniak ${ }^{2}$ oraz popularność takich grupy dyskusyjnych, jak Zioła $i$ terapie naturalne (ponad 37000 członków - dane z dnia 9 września 2021 r.) powoduje, że zainteresowanie naturalnymi metodami leczenia w społeczeństwie polskim jest zdecydowanie ożywione. Nieustannie słychać również głosy przeciwników i sceptyków, tematyka stosowania CAM wciąż budzi ogromne kontrowersje i niejednokrotnie zdecydowane kontrdzialania, czego przykład również możemy znaleźć w mediach społecznościowych. Znajdziemy w nich profile popularyzatorów nauki, którzy aktywnie publikują materiały, które polemizują z treściami rozpowszechnianymi przez zwolenników CAM. Są to np. profil ANTY-Ukryte Terapie-Bzdury Jerzego, który stoi w opozycji do działalności wspomnianego wyżej Jerzego Zieby, który obserwuje ponad 11 tys. internautów, profil Pseudonauki Altmedu i Bajki Dla Dorostych (ok. 3500 tzw. polubień), profil lekarza Dawida Ciemięgi (ponad 84000 osób obserwujących) czy Teoretycznie tak-grupa pro naukowa, która skupia ponad 70000 miłośników nauki (wszystkie wymienione dane dotyczące profili przeciwników CAM pochodzą z dnia 9 września 2021 r.). Ostrzeżenia przed korzystaniem z praktyk nieuczciwych znachorów czy stosowaniem na własną rękę niezweryfikowanych naukowo pseudoterapii regularnie pojawiają się $\mathrm{w}$ mediach $\mathrm{w}$ wypowiedziach specjalistów, dziennikarzy, a nawet w perypetiach serialowych bohaterów. Widać wyraźnie, że dynamika ścierania się poglądów anty- i proCAM w Polsce nie słabnie.

Widać wyraźnie, że stosowanie CAM oraz szanse i zagrożenia z nimi związane stanowią ważny temat społeczny, będący przedmiotem zainteresowań wielu nauk. W niniejszym artykule skupiono się na poszukiwaniu psychologicznych uwarunkowań zjawiska.

Dokonano przeglądu baz danych dostępnych w zasobach Ebsco, tj. Medline, ApaPsycArticles, APA PsycInfo, CINAHL, oraz w wyszukiwarce Google Scholar. Korzystano ponadto ze spisów bibliograficznych zawartych w poszczególnych artykułach oraz własnych zasobów literatury zgromadzonej w wyniku zainteresowań badawczych tematyką CAM. W przeglądzie brano pod uwagę prace badawcze pochodzące z lat 1990-2021. Wykluczono artykuły odnoszące się do pojedynczych metod terapii CAM, analizowano wyłącznie prace, które odnoszą się do stosowania wielu CAM.

\section{Stan badań}

Fakt ogromnej popularności i kontrowersji wokół CAM budzi zainteresowanie badaczy z różnych dyscyplin nauk społecznych zwłaszcza psychologii i socjologii od kilku dekad. Badania nad uwarunkowaniami postaw wobec CAM prowadzonymi na świecie przyniosły wiele ciekawych obserwacji, wciąż są prężnie prowadzone na całym świecie. W Polsce duże zdobycze w tym zakresie ma polska socjologia, zwłaszcza okręg lubelski reprezentowany przez badaczy skupionych wokół prof. dr hab. Włodziemierza Piątkowskiego, natomiast badań psychologicznych jest bardzo mało - poza monografią i badaniami

\footnotetext{
1 Z uwagi na kontrowersyjne wypowiedzi Jerzego Zięby, w tym zdecydowane popieranie ruchów antyszczepionkowych szereg osób i instytucji podjęło kroki prawne, aby ograniczyć jego działalność w Internecie, m.in. usunięto najpopularniejsze wykłady z Youtube

${ }^{2}$ W 2020 roku Naczelny Sąd Lekarski zawiesił Hubertowi Czerniakowi prawo do wykonywania zawodu lekarz na 2 lata. Powodem decyzji sądu było propagowanie antyzdrowotnych postaw odnośnie szkodliwości szczepień.
} 
Olchowskiej-Kotali [12,13], badaniami Dolińskiej-Zygmunt [14] oraz Mellibrudy, Lesiak i Sikory [15] nie ma żadnych opracowań wpisujących się w nurt poszukiwania psychologicznych uwarunkowań zjawiska popularności CAM.

To, co wiemy, na temat psychologicznych uwarunkowań stosowania CAM dotyczy różnorodnych czynników związanych z poszczególnymi sferami funkcjonowania człowieka, począwszy od zmiennych o charakterze socjodemograficznym przez szereg czynników o charakterze poznawczym i związanym z duchowością [16-18].

$\mathrm{Na}$ początku przedstawione zostaną czynniki socjodemograficzne i środowiskowe związane z CAM. W dalszej kolejności natomiast zaprezentowane zostaną typy poznawcze rozumiane jako dominujący u jednostki sposób przetwarzania i wartościowania informacji, następnie przekonania i charakterystyki światopoglądowe wraz z elementami duchowości i religijności wreszcie pozostałe cechy sprzyjające pozytywnym postawom wobec CAM.

Zdecydowana większość badań płynących z różnych części świata co najmniej od lat 90-tych ubiegłego wieku mówi o tym, że CAM najważniejszymi predykatorami CAM są płeć kobieca, wiek 25-49 lat, wyższy dochód oraz wyższe wykształcenie (!) $[6,19,20]$. Ważne są również takie aspekty, jak dostępność CAM, ich rozpowszechnienie w społeczności oraz tradycje rodzinne korzystania $\mathrm{z}$ opieki zdrowotnej wyniesione $\mathrm{z}$ domu [21-23]. Do najważniejszych zmiennych związanych z silniejszą tendencją do korzystania z CAM należą jednak czynniki poznawcze.

\section{Style poznawcze i przekonania}

W zakresie uwarunkowań o charakterze poznawczym, interesujących wyników dostarczyły badania nad stylami poznawczymi. Wykazały one, że charakterystyczną cechą osób stosujących CAM jest częściej intuicyjny, a rzadziej racjonalny styl myślenia [12,24-26]. Oznacza to, że osoby te częściej cechuje tendencja do globalnego sposobu odbioru i oceny informacji, domyślania się i opierania na przeczuciach, wykraczania poza dostępne dane, poszukiwanie spójności i całości wśród nieuporządkowanych danych w przeciwieństwie do racjonalnego stylu myślenia polegającego na przetwarzaniu informacji w sposób podporządkowany logicznej spójności, obiektywności, krytycyzmowi, wnikliwości, praktyczności i zwracaniu uwagi na konsekwencje decyzji [12]. Jednakże warto zaznaczyć, iż u pacjentów nowotworowych, zmienną która sprzyja próbom stosowania CAM okazał się styl poznawczy nie tylko intuicyjny, ale również racjonalny [13]. Różnice te wynikać mogą oczywiście z uwarunkowań sytuacyjnych i związanych ze stanem zdrowia.

Zwolennicy CAM częściej odznaczają się niższym poziomem motywacji o charakterze poznawczym wyrażającym się m.in. w potrzebie domknięcia [27] przy czym w tej kwestii istnieją rozbieżności w badaniach. Zdecydowanie również rzadziej charakteryzuje ich skłonność do naukowego rozumowania (scientific reasoning) i krytycznego myślenia [28,29] częściej natomiast myślenie magiczne [24,30] oraz wiara w przesądy i teorie spiskowe [24,31-33]. Badania wykazały również, że częściej osoby o pozytywnej postawie wobec CAM wierzą $\mathrm{w}$ zjawiska $[12,24]$ oraz inne trudne do wyjaśnienia fenomeny $\mathrm{np}$. intencjonalne korzystanie z zasobów tzw. energii [24,34]. Osoby przychylnie nastawione do CAM częściej również charakteryzuje twórczość jako styl poznawczy wyrażający się pomysłowością, giętkością, otwartością, spontanicznością oraz tendencją do podejmowania ryzyka i eksperymentowania poznawczego [12]. Przypuszczalnie dlatego dużo łatwiej znieść tym osobom towarzyszący sceptykom dysonans poznawczy i podejmowanie prób leczenia metodami o niezweryfikowanym statusie naukowym.

Osoby korzystające z CAM często deklarują, że fakt stosowania CAM nie jest wyizolowanym $\mathrm{z}$ ich osobowości i systemu wartości jednostkowym aktem behawioralnym, lecz stanowi element spójny z innymi postawami, przekonaniami i światopoglądem jednostki 
[16,18,21,35]. Mimo, iż zwolennicy CAM w mniejszym stopniu wykazują potrzebę zdobycia dogłębnej i wyczerpującej wiedzy na temat różnych aspektów rzeczywistości, starają się jednak zbudować wokół CAM względnie spójną reprezentację poznawczą wyrażającą się w pewnych charakterystycznych dla tych osób przekonań. Można je podzielić na trzy grupy: związane $\mathrm{z}$ negatywną oceną medycyny konwencjonalnej, pozytywną oceną CAM oraz pozostałą grupą przekonań częściej wyznawaną przez użytkowników CAM, które zasygnalizowano wcześniej (wiara w zjawiska paranormalne, spiskowe), które związane są z uwarunkowaniami o charakterze poznawczym. Warto przybliżyć zatem kontekst przekonań związanych z rozczarowaniem medycyną konwencjonalną oraz z pozytywnym obrazem CAM.

Dyssatysfakcja z doświadczeń i osiągnięć medycyny konwencjonalnej to czynnik, który od dawna pojawia się w wynikach badań na uwarunkowaniami stosowania CAM m.in. $[4,36]$. Mimo ogromnych postępów, jakie medycyna konwencjonalna poczyniła w ostatnich latach, prężnego rozwoju nowoczesnych technologii i metod farmakoterapii, coraz więcej osób odwraca się od medycyny akademickiej na rzecz CAM. Medycynie konwencjonalnej zarzuca się podejście biomedyczne, patogenetyczne, skupione na biologicznych aspektach choroby i metod jej leczenia, ignorowanie innych wymiarów zdrowia człowieka, tj. np. psychicznego, społecznego, duchowego i pomijanie tych czynników jako potencjalnie zarówno chorobotwórczych, jak i terapeutycznych. Metody farmakoterapii coraz częściej są odrzucane jako niebezpiecznie, nieskuteczne, niosące wiele uciążliwych skutków ubocznych. Pojawiły się przekonania, że pacjent i jego zdrowie stanowi narzędzie zysku dla bogacących się stale firm farmaceutycznych, których celem nie jest wyleczenie, lecz możliwie najdłuższe zażywanie leków [33,37-39]. Z tym związane są również charakterystyczne dla wielu zwolenników CAM postawy antyszczepionkowe [30,40]. Budzi sprzeciw także wkraczanie medycyny $\mathrm{w}$ nowe obszary życia, czyli tzw. medykalizacja i stwarzanie na tej podstawie nowych jednostek chorobowych, które należy leczyć [37,41]. Wiele osób zwraca również uwagę na mankamenty funkcjonalne służby zdrowia związane z odległymi terminami przyjęć, ograniczoną infrastrukturą placówek medycznych, nadmierną biurokracją i krótkimi wizytami $[12,42]$. Wreszcie dyssatysfakcja $\mathrm{z}$ medycyny konwencjonalnej obejmuje również postrzeganie postaw personelu medycznego jako niewłaściwych, nieskoncentrowanych na pacjencie, pomijających jego rolę $\mathrm{w}$ procesie leczenia oraz niezadowolenie $\mathrm{z}$ komunikacji na linii lekarz - pacjent [38,43,44]. Wszystkie wymienione czynniki powodują, że niezadowolenie $\mathrm{z}$ doświadczeń $\mathrm{z}$ medycyną konwencjonalną $\mathrm{i}$ jej negatywna ocena stanowią jeden z najważniejszych czynników sięgania po metody CAM. Jak pisze Piątkowski, w obrębie oferty CAM pacjent odnajduje możliwość realizowania potrzeb, których nie może zrealizować na gruncie medycyny konwencjonalnej [6].

Równocześnie korzystaniu z CAM najczęściej towarzyszy pozytywne nastawienie do tego rodzaju metod leczenia. Zwolennicy CAM wierzą, że terapie CAM są skuteczne i bezpieczne, że niosą niskie prawdopodobieństwo skutków ubocznych. Wierze i przekonaniu o ich bezpieczeństwie towarzyszy założenie, że stosowanie tego, co stworzyła natura jest idealnym środkiem leczniczym o niskim ryzyku negatywnego wpływu na zdrowie. To również przekonanie o wysokiej skuteczności terapii CAM i wysokim prawdopodobieństwie poprawy stanu zdrowia. Co ważne, tendencji do stosowania CAM sprzyja przeświadczenie o braku nieprzyjemnych doznań towarzyszących leczeniu i poczucie rozumienia tego, w jaki sposób terapia wpływać będzie na organizm. Wszystkie te przekonania wpływają na obniżenie lęku związanego z leczeniem [12].

Zawartość treściowa przekonań zdrowotnych osób korzystających z CAM bardzo często składa się na tzw. holistyczną orientację zdrowotną, traktującą organizm człowieka jako doskonałą całość, obejmująca pogląd, że zdrowie człowieka jest wielowymiarowe oraz będące wynikiem oddziaływania na nie wielu odrębnych czynników (m.in. fizycznych, psychicznych, społecznych, duchowych) [45,46]. Podejście holistyczne zakłada 
wykorzystanie wszystkich tych czynników w procesie leczenia i postrzeganie choroby przez pryzmat wielu patomechanizmów. Holistyczna orientacja zdrowotna docenia i wierzy głęboko w zdolność organizmu do samo leczenia i postuluje wspieranie tych procesów. Z tym związana jest częściej występująca u zwolenników CAM chęć partycypacji w procesie leczenia i podejmowania odpowiedzialności za swoje zdrowie $[38,47]$. Osoby korzystające $z$ CAM wierzą we własne możliwości sprawowania kontroli nad procesami zdrowienia, wykazują większe ogólne zainteresowanie sprawami zdrowia i wyższy poziom umiejętności zdrowotnych $[48,49]$. Osiągają one również wyższe wyniki w zakresie wewnętrznego umiejscowienia kontroli zdrowia [50]. Zwolenników CAM w sposób interesujący opisuje [38]. Pisze on, iż osoby korzystające z CAM „wykazują większe zainteresowanie zrozumieniem znaczenia choroby, to pacjenci dążący do poznania i doświadczenia, nadania sensu temu, co dzieje się aktualnie $\mathrm{w}$ ich ciele, do ponownego skategoryzowania siebie $\mathrm{i}$ przeformułowania tradycyjnych pojęć, takich jak życie, choroba, ciało, itd. W tym celu, użytkownicy CAM dokonują zindywidualizowanych poszukiwań medycyny lub terapeutycznych , itinerariów", które działają w ich przypadku” [38]. Z tego punktu widzenia potrzeba autonomii jest centralnym czynnikiem napędzającym stosowanie CAM.

Rozważania te stoją w sprzeczności z tym, co w swoich badaniach uzyskała Dolińska - Zygmunt [14], która wykazała, iż zwolennicy CAM częściej deklarują zależność zdrowia od czynników zewnętrznych, tj. tzw. mocnych (Boga, lekarzy). Wielu autorów godzi jednak te sprzeczności uzasadniając to faktem, iż ludzie wykorzystują różne sposoby atrybucji w kwestiach podejścia do swojego zdrowia.

\section{Światopogląd, sfera religijności i duchowości}

Wiara w leczniczą moc natury i holistyczna orientacja zdrowotna stanowią niejednokrotnie u użytkowników CAM część większego systemu filozoficznego czy światopoglądowego. Sami korzystający z CAM podkreślają, że stosowanie CAM jest zgodne i spójne $z$ ich filozofią życiową i poglądami [35,51]. Grupę zwolenników CAM częściej charakteryzuje posiadanie tzw. postmaterialistycznych poglądów, które akcentują potrzebę odejścia od wartości materialnych i skupienie się na problemach i prawach człowieka, na rzecz lepszej jakości życia [44]. Osoby wybierające terapie CAM częściej są zwolennikami ekologii i częściej należą do grupy tzw. cultural creatives ${ }^{3}$ - osób zainteresowanych ochroną środowiska, rozwojem osobistym ezoteryką, niekonwencjonalnym formami duchowości, zamiłowaniem do egzotyki [52]. Same również częściej uważają się za osoby niekonwencjonalne [42]. Zdaniem teoretyków, u podłoża popularności CAM leży również healism charakteryzujący się kultem zdrowego i pięknego ciała, modą na ekologiczny, zgodny z naturą model życia, obejmujący również korzystanie $\mathrm{z}$ naturalnych sposobów leczenia [7].

Zwolennicy CAM częściej deklarują bycie osobą religijną bądź uduchowioną; częściej deklarują one także pogłębione życie duchowe bez przynależności do konkretnego systemu religijnego bądź akcentują jako ważne pozaformalne i pozainstytucjonalne aspekty życia religijnego [28,53-55].

Co ciekawe, z badań wynika, że religijni lekarze częściej zalecają CAM swoim pacjentom [56].

Elementy religijności i duchowości bardzo często współwystępują z CAM holistyczne podejście do zdrowia oraz schematy uzdrawiania $\mathrm{w}$ poszczególnych terapiach

\footnotetext{
${ }^{3}$ Wyróżniona grupa pochodzi z typologii mieszkańców USA lat 60-tych, stworzonej przez Raya, który obok tzw. cultural creatives wyróżnia także the moderns czyli osoby podążające za popkulturą i nowoczesnością oraz the heartlanders, których cechuje konserwatyzm i tradycyjne poglądy.
} 
CAM podkreślają istotę sfery duchowej w procesie dochodzenia do zdrowia. Poszczególne praktyki religijne, m.in. joga, medytacja, modlitwa uważane są za terapie z kręgu CAM. Istnieją także takie metody CAM, tj. tzw. spiritual healing lub faith healing, w których sam czynnik duchowy jest podstawą leczenia i warunkiem zdrowienia [57]. Modlitwa o uzdrowienie dzięki mocy Bożej Łaski jest także oficjalnie usankcjonowana przez Kościół Rzymskokatolicki i praktykowana przez rzesze wiernych [58,59]. Wiele elementów religijnych, duchowych, spirytystycznych czy mistyczno-magicznych wykorzystywanych jest w praktykach uzdrowicieli czy tzw. healerów zarówno jako sposób na przyciągnięcie klienta, jak i jego leczenia. Bardzo dużo na temat tych praktyk w swoich licznych studiach socjologicznych Piątkowski oraz ostatnio [60] Michalik i Janiszewska [61] - wymienione prace omawiają także fenomeny uzdrowicieli działających na terenie Polski, np. Zbigniew Nowak czy Kaszpirowski.

CAM są popularne również $w$ pewnych grupach religijnych, np. zakonnych, gdzie bardzo często praktykuje ziołolecznictwo. Zakonnicy z jednej strony podkreślają sprawdzoną i niezawodną skuteczność ziół, $\mathrm{z}$ drugiej zaś u podstaw ich działalności leży wiara w leczniczą moc natury stworzonej przez Boga [62]. W sposób oczywisty afirmacja osób duchownych może być czynnikiem motywującym do wyboru CAM jako sposobu leczenia przez wiernych.

\section{Czynniki emocjonalne i osobowościowe}

Oprócz czynników związanych ze stylami poznawczymi, przekonaniami, światopoglądem, duchowością i religijnością istnieją badania, które donoszą o specyficznych cechach osobowości towarzyszących pozytywnemu nastawieniu do CAM. Większość badań w tym zakresie została zrealizowana w oparciu o model tzw. Wielkiej Piątki. Wśród czynników dodatnio skorelowanych ze stosowaniem CAM znajdują się otwartość na doświadczenie (bardzo silny predykator), ekstrawersja, neurotyczność, ujemnie natomiast sumienność. Należy jednak zaznaczyć, że w zakresie badań wykorzystujących model Wielkiej Piątki istnieją rozbieżności w otrzymanych wynikach poszczególnych badaczy $[12,55,63,64]$. Podobnie, jeśli chodzi o typ emocjonalności, mamy do czynienia ze skrajnie różnymi wynikami - z jednej strony istnieją badania, które donoszą o afekcie pozytywnym, inne o gorszym samopoczuciu i większym nasileniu cechy lęku u zwolenników CAM $[42,63,65,66]$. Z kolei niektóre badania wskazują na większy poziom dyspozycyjnego optymizmu [45], inne o ujemnej korelacji stosowania CAM i optymizmu [55]. Jeśli chodzi o inteligencję emocjonalną, kontrolę emocji, samoregulację, style radzenia sobie i tym podobne miary przystosowania i efektywnego funkcjonowania, badań jest bardzo mało, a ich wyniki także nie są spójne [26,67,68]. Czynniki emocjonalne i związane z procesami radzenia sobie mogą jednak odgrywać ważną rolę w procesach decyzyjnych dotyczących zdrowia i choroby.

\section{Podsumowanie}

Widać wyraźnie, że spośród psychologicznych czynników determinujących pozytywne postawy wobec CAM dotychczas najlepiej poznano czynniki poznawcze i światopoglądowe, najmniej wiemy natomiast o czynnikach związanych ze sferą emocji i osobowości. Istniejących badań jest relatywnie niewiele i jak pokazano w niniejszym artykule, niejednokrotnie niosą ze sobą sprzeczne wyniki. Z pewnością warto, aby psychologiczne badania nad poznawczymi, osobowościowymi i emocjonalnymi korelatami postaw wobec CAM były kontynuowane w celu wyjaśnienia istniejących rozbieżności oraz celem ustalenia nowych istotnych zmiennych w omawianym zakresie. 
Warto ponadto zauważyć, iż wiele badań, zwłaszcza dotyczących duchowości i światopoglądu ma ponad 20 lat, większość z nich prowadzona była w ówczesnych amerykańskich kręgach kulturowych. Rodzi się pytanie, jak zjawisko stosowania CAM funkcjonuje w kulturze współczesnej, w epoce pandemii, która wymusza stawianie nowych pytań i penetrowanie nowych obszarów badawczych związanych z postawami zdrowotnymi. Wydaje się również, że zjawisko może mieć swój specyficznych kontekst polski związanych ze strukturą ludności i ciągle żywą obecnością lecznictwa ludowego (por. Piątkowski, 2020), a także polskiej religijności, w której duża część społeczeństwa deklaruje wyznanie katolickie. Wymaga to jednak dalszych pogłębionych badań.

$\mathrm{Z}$ uwagi na to, iż z postaw i zachowań zdrowotnych w dużej mierze wynikać będzie stan zdrowia poszczególnych jednostek, warto podejmować badania nad ich uwarunkowaniami. Niesłabnąca popularność CAM będzie istotnie wpływać na zdrowie pacjentów, co implikuje potrzebę dogłębnego poznania czynników i mechanizmów leżących u podstaw zjawiska. Pozwoli to na lepsze zrozumienie potrzeb i oczekiwań pacjentów, a także na podejmowanie działań mających na celu wzrost bezpieczeństwa zdrowotnego ludności.

\section{Lista piśmiennictwa}

1. National Center for Complementary and Alternative Medicine. Expanding Horizons of Healthcare. Five Year Strategic Plan 2001-2005. 2000.

2. Piątkowski W. Spotkania $\mathrm{z}$ inną medycyną [Meetings with over medicine]. Lublin: Wydawnictwo Lubelskie; 1990.

3. Piątkowski W. Lecznictwo niemedyczne. Wybrane aspekty socjologiczne i formalnoprawne [Non-medical treatment. [Selected sociological and formal-legal aspects] Vol. 2, Konteksty społeczne. 2014. 7-20 p.

4. Tangkiatkumjai M, Boardman H, Walker D. Potential factors that influence usage of complementary and alternative medicine worldwide: a systematic review. BMC Complement Med Ther. 2020;20(363):1-15. https://doi.org/10.1186/s12906-02003157-2

5. CBOS. Horoskopy, wróżby, talizmany - czyli magia wokół nas - Raport z badań [Horoscopes, fortune telling, talismans - that is magic around us - Research report]. Warszawa; 2011.

6. Goldstein M. The Emergence of Alternative Medicine. In: Brown P, editor. Perspectives in Medical Sociology. Long Grove: Waveland Press; 2000. p. 363-72.

7. Piątkowski W. Lecznictwo niemedyczne w Polsce. Tradycja i współczesność [Nonmedical treatment in Poland. Tradition and contemporaneity]. Lublin: Wydawnictwo Uniwesrsytetu Marii-Curie Skłodowskiej; 2008.

8. WHO. WHO Traditional Medicine Strategy 2014-2023. Altern Integr Med [Internet]. 2013;1-76. Available from: http://apps.who.int/iris/bitstream/10665/92455/1/9789241506090_eng.pdf?ua=1 (Accessed 09.09.2016)

9. National Center for Complementary and Integrative Health. NCCIH Strategic Plan FY 2021- 2025. Mapping a Pathway to Research on Whole Person Health. 2021. Available from: https://nccih.nih.gov/about/nccih-strategic-plan-2021-2025

10. Orr DE, Fette D. From parallel to partnership. Factors that develop integrative relationships between biomedical and alternative medical practitioners. Leadersh Heal Serv. 2019;32(4):493-508. https://doi.org/10.1108/LHS-12-2018-0063

11. Towarzystwo Lekarzy Medycyny Zintegrowanej. Statut. 2017. Available from: https://tlmz.pl/statut 
12. Olchowska-Kotala A. Kto i dlaczego leczy się niekonwencjonalnymi metodami terapii? [Who and why are treated with unconventional methods of therapy?]

Toruń: Adam Marszałek; 2009.

13. Olchowska-Kotala A. Individual Differences in Cancer Patients' Willingness to Use Complementary and Alternative Medicine. Adv Clin Exp Med. 2013;22(6):855-60.

14. Dolińska-Zygmunt G. Podmiotowe wyznaczniki korzystania z praktyk medycyny alternatywnej. Szt leczenia. 2000;4:69-74.

15. Mellibruda L., Lesiak M., Sikora D. Z-CB. Uzdrowiciele - Raport z badań. [HealersResearch Report]Warszawa; 1985.

16. Bishop FL, Yardley L, Lewith GT. A Systematic Review of Beliefs Involved in the Use of Complementary and Alternative Medicine. J Health Psychol. 2007;12(6):85167. http://journals.sagepub.com/doi/10.1177/1359105307082447

17. Galbraith N, Moss T, Galbraith V, Purewal S. A systematic review of the traits and cognitions associated with use of and belief in complementary and alternative medicine (CAM). Psychol Heal Med. 2018;23(7):854-69. https://doi.org/10.1080/13548506.2018.1442010

18. Sirois FM, Salamonsen A, Kristoffersen AE. Reasons for continuing use of Complementary and Alternative Medicine (CAM) in students: a consumer commitment model. BMC Complement Altern Med. 2016 Feb;16:75. https://doi.org/10.1186/s12906-016-1059-3

19. Guillaud A, Darbois N, Allenet B, Pinsault N. Predictive factors of complementary and alternative medicine use in the general population in Europe: A systematic review. Complement Ther Med. 2019;42:347-54. https://doi.org/10.1016/j.ctim.2018.12.014

20. Fjær EL, Landet ER, McNamara CL, Eikemo TA. The use of complementary and alternative medicine (CAM) in Europe. BMC Complement Med Ther. 2020;20(1):108. https://doi.org/10.1186/s12906-020-02903-w

21. Lobera J, Rogero-García J. Scientific Appearance and Homeopathy. Determinants of Trust in Complementary and Alternative Medicine. Health Commun. 2020 Apr 14;1-8. Available from: https://doi.org/10.1080/10410236.2020.1750764

22. Thi L, Phuc N, Felix MS. Scoping Review: An Anthropological Analysis of the Beliefs of the Elderly That Influence the Use of Traditional /Complementary and Alternative Medicine. Asia-Pacific Soc Sci Rev. 2020;20(4):136-49.

23. Welz AN, Emberger-Klein A, Menrad K. What motivates new , established and longterm users of herbal medicine : is there more than push and pull ? BMC Complement Altern Med. 2019;7:1-10. https://doi.org/10.1186/s12906-019-2584-7

24. Saher M, Lindeman M. Alternative medicine: A psychological perspective. Pers Individ Dif. 2005;39(6):1169-78. https://doi.org/10.1016/j.paid.2005.04.008

25. Lindeman M. Biases in intuitive reasoning and belief in complementary and alternative medicine. Psychol Health. $2011 \quad$ Mar;26(3):371-82. https://doi.org/10.1080/08870440903440707

26. Won C. Personality, emotional intelligence, intuitive thinking and attitude towards complementary and alternative medicine. Alliant International University; 2014.

27. Svedholm AM, Lindeman M. Healing, Mental Energy in the Physics Classroom: Energy Conceptions and Trust in Complementary and Alternative Medicine in Grade 10-12 Students. Sci Educ [Internet]. 2013;22(3):677-94. Available from: https://doi.org/10.1007/s11191-012-9529-6

28. Cavojova V, Ersoy S. The role of scientific reasoning and religious beliefs in use of complementary and alternative medicine. J Public Health (Bangkok). 2020;42(3). https://doi.org/10.1093/pubmed/fdz120

29. Lobera J, Rogero-Garcia J. Accepted Manuscript Scientific Appearance and 
Homeopathy . Determinants of Trust in complementary and alternative medicine To appear in: Health Communication. Health Commun. 2020;36(10):1278-85. https://doi.org/10.1080/10410236.2020.1750764

30. Bryden GM, Browne M, Rockloff M, Unsworth C. Anti-vaccination and pro-CAM attitudes both reflect magical beliefs about health. Vaccine. 2018;36(9):1227-34. https://doi.org/10.1016/j.vaccine.2017.12.068

31. Galliford N, Furnham A. Individual difference factors and beliefs in medical and political conspiracy theories. Scand J Psychol. 2017 Oct 1;58(5):422-8. https://doi.org/10.1111/sjop.12382

32. Oliver JE, Wood T. Medical Conspiracy Theories and Health Behaviors in the United States. JAMA Intern Med.. 2014 May 1;174(5):817-8. https://doi.org/10.1001/jamainternmed.2014.190

33. Lamberty P, Imhoff R. Powerful Pharma and Its Marginalized Alternatives? Soc Psychol (Gott). 2018 Jul 30;49(5):255-70. Available from: https://doi.org/10.1027/1864-9335/a000347

34. Jeswani M, Furnham A. Are modern health worries, environmental concerns, or paranormal beliefs associated with perceptions of the effectiveness of complementary and alternative medicine? Br J Health Psychol. 2010 Sep;15(Pt 3):599-609.

35. Chowdhuri PD, Kundu K. Factors determining choice of complementary and alternative medicine in acute and chronic. J IComplementary ntegrative Med. 2020;17(3). https://doi.org/10.1016/j.vaccine.2017.12.068

36. Zörgö S, Peters G-JY, Mkhitaryan S. Attitudes Underlying Reliance on Complementary and Alternative Medicine. Integr Cancer Ther. 2020 Jan 1;19:1534735420910472. https://doi.org/10.1177/1534735420910472

37. Piątkowski W, Nowakowski M. Procesy medykalizacji we współczesnym społeczeństwie [Medicalization processes in contemporary society]. Nowakowski, Michał, Piątkowski W, editor. Lublin: UMCS; 2017.

38. MacArtney JI, Wahlberg A. The Problem of Complementary and Alternative Medicine Use Today. Qual Health Res. 2014;24:114-23. https://doi.org/10.1177/1049732313518977

39. Zörgő S, Purebl G, Zana Á. A qualitative study of culturally embedded factors in complementary and alternative medicine use. BMC Complement Altern Med. 2018;18(1):25. https://doi.org/10.1186/s12906-018-2093-0

40. Wardle J, Frawley J, Steel A, Sullivan E. Complementary medicine and childhood immunisation: A critical review. Vaccine. 2016;34(38):4484-500. https://doi.org/https://doi.org/10.1016/j.vaccine.2016.07.026

41. Nowakowski M. Medykalizacja i demedykalizacja. Zdrowie i choroba w czasach kapitalizmu zdezorganizowanego [Medicalization and demedicalization. Health and Illnes in times of disorganized capitalism]. Lublin: UMCS; 2015.

42. McGregor K, Paey R. The choice of alternative therapy for health care: Testing some propositions. Soc Sci Med. 1996;43(9):1317-27.

43. Fionda S, Furnham A. Hypochondriacal attitudes and beliefs, attitudes towards complementary and alternative medicine and modern health worries predict patient satisfaction. JRSM Open. 2014;5(11):1-10. https://doi.org/10.1177/2054270414551659

44. Messerli-Rohrbach V. Personal values and medical preferences: postmaterialism, spirituality, and the use of complementary medicine. Forschende Komplementarmedizin und Klass Naturheilkd $=$ Res Complement Nat Class Med. 2000 Aug;7(4):183-9.

45. Arthur K, Belliard JC, Hardin SB, Knecht K, Chen C-S, Montgomery S. Practices, 
Attitudes, and Beliefs Associated With Complementary and Alternative Medicine (CAM) Use Among Cancer Patients. Integr Cancer Ther. 2012 Feb 7;11(3):232-42. https://doi.org/10.1177/1534735411433832

46. Thomson P, Jones J, Browne M, Leslie SJ. Psychosocial factors that predict why people use complementary and alternative medicine and continue with its use: A population based study. Complement Ther Clin Pract. 2014;20(4):302-10. https://doi.org/https://doi.org/10.1016/j.ctcp.2014.09.004

47. Attwell K, Ward PR, Meyer SB, Rokkas PJ, Leask J. "Do-it-yourself": Vaccine rejection and complementary and alternative medicine (CAM). Soc Sci Med.2018;196:106-14. https://doi.org/https://doi.org/10.1016/j.socscimed.2017.11.022

48. Bains SS, Egede LE. Association of health literacy with complementary and alternative medicine use: a cross-sectional study in adult primary care patients. BMC Complement Altern Med. 2011 Dec 30;11:138. https://doi.org/10.1186/1472-6882-11-138

49. Gardiner P, Mitchell S, Filippelli AC, Sadikova E, White LF, Paasche-Orlow MK, et al. Health literacy and complementary and alternative medicine use among underserved inpatients in a safety net hospital. J Health Commun. 2013;18 Suppl 1(Suppl 1):290-7. https://doi.org/10.1080/10810730.2013.830663

50. Schützler L, Witt CM. Internal health locus of control in users of complementary and alternative medicine: a cross-sectional survey. BMC Complement Altern Med. 2014 Aug;14(1):1-9. https://doi.org/10.1186/1472-6882-14-320

51. Popper-Giveon A, Schiff E, Ben-Arye E. I will always be with you: Traditional and complementary therapists' perspectives on patient-therapist-doctor communication regarding treatment of Arab patients with cancer in Israel. Patient Educ Couns. 2012;89(3):381-6. https://doi.org/10.1016/j.pec.2012.03.016

52. Astin JA. Why Patients Use Alternative Medicine Results of a National Study. J Am Med Assoc. 1998;279(19):1548-1553.

53. Abheiden H, Teut M, Berghöfer A. Predictors of the use and approval of CAM: results from the German General Social Survey (ALLBUS). BMC Complement Med Ther. 2020;20(1):183. https://doi.org/10.1186/s12906-020-02966-9

54. Kralj Ž, Kardum G. Attitudes toward complementary and alternative medicine, beliefs in afterlife and religiosity among psychiatrists, psychologists and teologists. Psychiatr Danub. 2020;32(3):420-7. doi: 10.24869/psyd.2020.420.

55. Smith BW, Dalen J, Wiggins KT, Christopher PJ, Bernard JF, Shelley BM. Who Is Willing to Use Complementary and Alternative Medicine? Explor J Sci Heal. 2008;4(6):359-67. https://doi.org/10.1016/j.explore.2008.08.001

56. Powers-James C, Alvarez A, Milbury K, Barbo A, Daunov K, Lopez G, et al. The Influence of Spirituality and Religiosity on US Oncologists' Personal Use of and Clinical Practices Regarding Complementary and Alternative Medicine. Integr Cancer Ther. 2020 Jan 1;19:1-6. https://doi.org/10.1177/1534735420945769

57. Jonas W, Levin J. Podstawy medycyny komplementarnej i alternatywnej. [Fundamentals of complementary and alternative medicine]. Kraków: Universitas; 2000.

58. Simão TP, Caldeira S, De Carvalho EC. The Effect of Prayer on Patients' Health: Systematic Literature Review. Vol. 7, Religions. 2016. p. 1-11. https://doi.org/10.3390/rel7010011

59. Wiecki A. Modlitwy o zdrowie - nadużycie czy wiara ? Refleksja pastoralna [Prayers for health - abuse or faith? Pastoral reflection]. Fides et Ratio. 2017;4(32):258-63.

60. Michalik G. Kaszpirowski. Sen o wszechmocy [Kaszpirowski. The dream of omnipotence]. Warszawa: Agora; 2020.

61. Janiszewska K. Ja nie leczę, ja uzdrawiam [I do not treat, I heal]. Kraków: Otwarte; 
2019.

62. Paczuska A. Zielnik klasztorny [Monastery herbarium]. Warszawa: RM; 2019.

63. Chowdhuri PD, Meyur S. Exploration of Personality Factors and their Effects on People s Decision Making of Complementary and Alternative Medicine. Int J Manag Stud. 2018;2(4):120-5. doi:10.18843/ijms/v5i2(4)/13

64. Sarris J, Goncalves DC, Robins Wahlin T-B, Byrne GJ. Complementary medicine use by middle-aged and older women: personality, mood and anxiety factors. J Health Psychol. 2011 Mar;16(2):314-21. https://doi.org/10.1177/1359105310375635

65. Mitzdorf U, Beck K, Horton-Hausknecht J, Weidenhammer W, Kindermann A, Takács $\mathrm{M}$, et al. Why do patients seek treatment in hospitals of complementary medicine? J Altern Complement Med. 1999 Oct;5(5):463-73.

66. Owens JE, Taylor AG, Degood D. Complementary and alternative medicine and psychologic factors: toward an individual differences model of complementary and alternative medicine use and outcomes. J Altern Complement Med. 1999 Dec;5(6):529-41.

67. Honda K, Jacobson JS. Use of complementary and alternative medicine among United States adults: The influences of personality, coping strategies, and social support. Prev Med (Baltim). 2005;40(1):46-53. https://doi.org/10.1016/j.ypmed.2004.05.001

68. LaCaille RA, Kuvaas NJ. Coping styles and self-regulation predict complementary and alternative medicine and herbal supplement use among college students. Psychol Health Med. 2011 May 1;16(3):323-32. https://doi.org/10.1080/13548506.2010.543909

69. Piątkowski W. From Medicine to Sociology. Health and Illness in Magdalena Sokołowska’s Research Conceptions. Berlin, Germany: Peter Lang Verlag; 2020. 